\title{
津波避難シミュレーションを用いた 津波避難タワーの効果の検討
}

\author{
小柳 雄揮 1 - 有川 太郎2 \\ 1中央大学大学院 理工学研究科都市環境学専攻（†112-8551東京都文京区春日1-13-27） \\ E-mail:koyanagi@civil.chuo-u.ac.jp \\ 2正会員 中央大学教授 理工学部都市環境学科（一112-8551東京都文京区春日1-13-27） \\ E-mail: arikawa@civil.chuo-u.ac.jp
}

\begin{abstract}
本研究では, 津波避難タワーを整備した地区を対象に, 津波シミュレータと連成させた避難シミュレ 一タを用いて, 津波の挙動と避難行動を同時に計算し, 津波避難タワーの有無による人的被害の違い や避難行動への影響を検証した。その結果, 本条件下においては, 沿岸部に近い場所に避難タワーを 設置した場合，避難開始時間によっては，津波に遭遇する可能性が高くなることがわかった。一方で， 避難開始時間が津波到達時間よりも早ければ，津波避難タワーによって，死亡率をかなり減少させる ことが確認できた。 また, 新たな津波避難タワーの設置した場合の効果についても検証し, 平均的な 避難距離を短くすることで，死亡者数が減少することがわかった.
\end{abstract}

Key Words : evacuation simulation, evacuation tower, evacuation start time, tsunami, STOC

\section{1. はじめに}

2011 年 3 月 11 日の東日本大震災以降, 想定される最 大クラスの津波の高さが増大し，従来のハード面の対策 だけでなく, ソフト面の強化がより重要となった. その ため，津波に強いまちづくりのための方策 1) が示され， 津波による浸水被害が生じる恐れがある地域を中心に， 人命を守るための円滑な避難行動を支える基盤を再検証 している. しかし，地震発生から津波到達までの時間的 な余裕が少なく，避難のための十分な時間を確保できな い地域も少なくない. そのため，対策の 1 つとして，津 波避難ビルや津波避難タワー等があげられ，津波避難ビ ル等の指定, 利用・運営手法等についてのガイドライン が内閣府 2) により作られている.

避難ビル等の有用性については，伊藤ら ${ }^{3)}$ が避難可 能距離, 収容可能距離指標と, 予想される津波浸水範囲 を重ねることで，どの場所が危険地帯になっているのか 検証を行っている. 一方で, 一度に多くの避難者の避難 行動，例えば海の方向へ避難するなどの行動や，避難場 所，避難開始場所，避難開始時間などによる影響を検討 するには，避難シミュレータ等を活用する必要がある ${ }^{4}$. そこで本研究では, 有川ら 5) の開発した, 非線形長波 方程式に基づく津波シミュレータと，マルチェージェン 卜を用いた避難シミュレータを連成させた津波避難シミ
ュレーションを用いて，津波挙動と避難行動を同時に計 算し, 津波避難タワーの有無による被害予測や避難行動 への影響を検証した。また，新たな津波避難タワーの設 置場所の選定及びそれに伴う避難行動への影響を検証し た.

シミュレーションを行った対象地域は，今後津波によ る甚大な被害が予想されている高知県のある地域である. この地域は，主要な産業が観光業と漁業であるため，沿 岸に近いエリアに住宅が集中しており，高台にある避難 所まで避難するのに時間を要する。 また同地域は, 幅の 狭い道が多く, 車での避難は難しいため, 避難行動を支 える対策として，2014年に 1つ目の津波避難タワーを設 置し, 続けて 2015 年に 2 つ目の津波避難タワーを整備 した. 整備された 1 つ目の津波避難タワーを写真-1 に 示す.

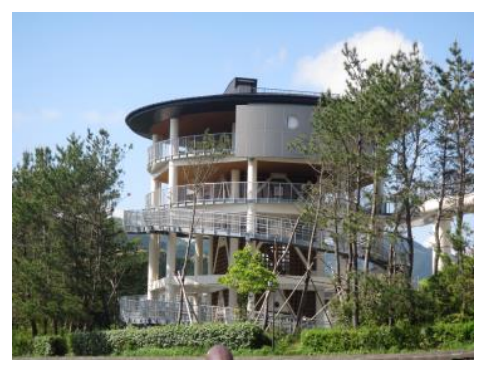

写真-1 対象地区の津波避難タワー 


\section{2. 津波避難シミュレータの概要}

(1) 津波避難シミュレータの概要

本研究では有川ら5)の開発した高潮津波シミュレータ STOC と連成させた津波避難シミュレータを用いる.

STOCと避難モデルを連成し，津波の挙動と避難行動を 同時に計算することで，津波規模と避難条件に応じた死 亡率の定量的な評価を可能としている。高潮津波シミュ レーションSTOCは，準3次元モデル（多層モデル）を用 いた静水圧近似のシミュレータであるSTOC-MLを用い た．避難シミュレータは，ポテンシャルモデルを使用し， 避難者は地形や障害物を考慮した避難所までの最短距離 経路を選択する．また避蜼速度は，八イキング関数によ り経路の勾配を考慮し，また浸水深による避難速度の補 正を行っている，浸水深は，STOCにより計算される值 を読み込むことにより設定する．避難シミュレーション のフローを図-1に示す，agentの死亡判定は，死亡判定水 深を設定し、その水深を超える浸水深を持つセルに含ま れる避難者を死亡判定としている. 本研究では死亡判定 水深を $1.0 \mathrm{~m}$ と設定した.

(2) 津波シミュレーションの計算条件

高潮津波シミュレーションSTOCの計算領域は，最小 の格子サイズを $10.0 \mathrm{~m}$ とた．波源は，中央防災会議に

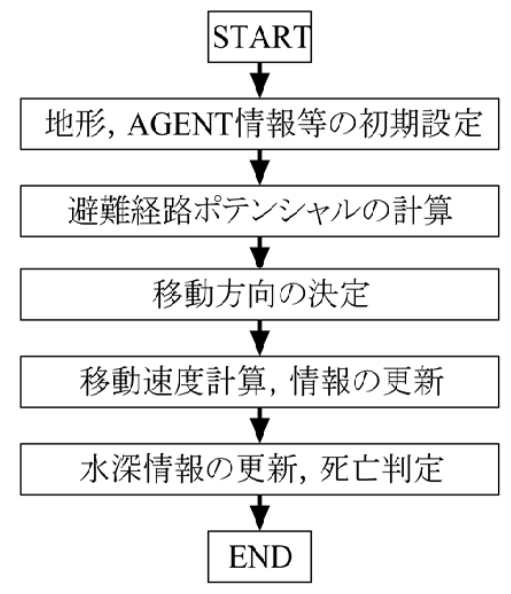

図-1＼cjkstart避難シミュレータのフロー図

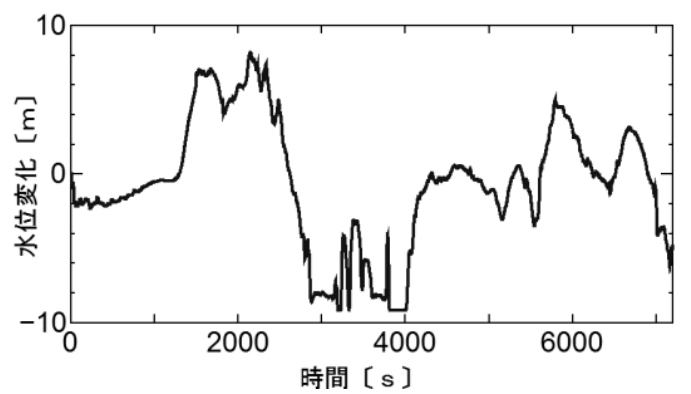

図-2＼cjkstart津波シミュレータによる水位変化
よる南海トラフ巨大地震のモデルケース6) のうち，最大 津波高，津波到着時間などから，最も被害が大きくなる と考えたケース4（四国沖に大すべり十超大すべり域） を使用した. この波源による対象地域の湾奧での水位変 化のグラフを図-2に示寸，以上の計算条件での，津波到 着時間と最大浸水深の計算結果を図-3，4 亿示寸

\section{3. 避難開始時間による津波避難タワーの効果}

\section{(1) 避難シミュレーションの計算条件}

設定した避難経路及び避難所の図を図-5に示す．また， 避難シミュレーションは，設定条件として避難者数2700 人, 初期の避難速度 $1.0 \mathrm{~m} / \mathrm{s}$ とし, 避難経路上にランダム に配置した。津波避難タワー整備後を想定した津波避難 タワー2基(図-5 2 2番，5番)を含む9力所を避難所に設定 したシミュレーションと，整備前を想定した津波避難夕 ワーを含まない避難所7カ所を設定したシミュレーショ ンを行った．このとき，避難者の避難開始時間は， $0 \mathrm{~s}$, $300 \mathrm{~s}$ と，600〜1800 sの間の100 s毎で設定を行った．避難 シミュレーションの詳細な条件を表-1に示す.

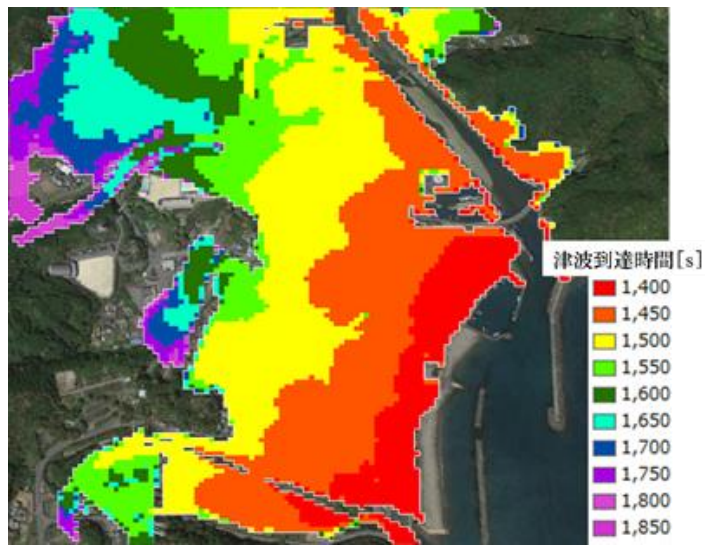

図-3 シミュレーションによる津波到達時間

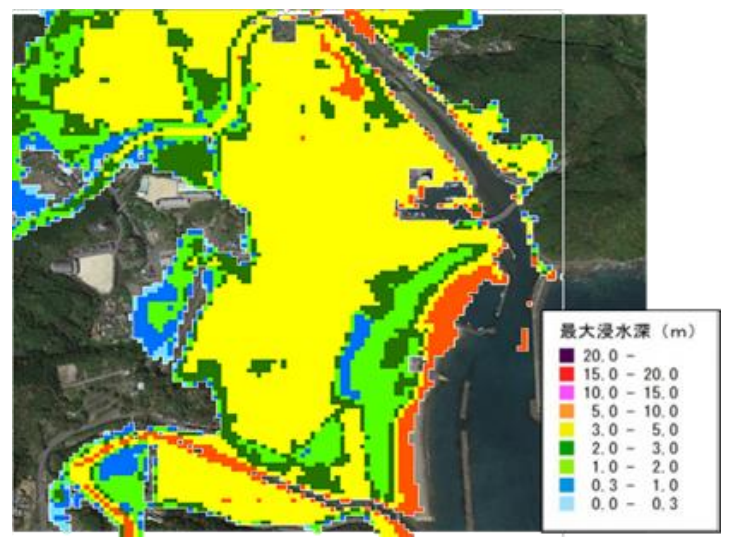

図-4 シミュレーションによる最大浸水深 


\section{（2）津波避難タワーの効果}

津波避難タワーの整備前後の避難を開始する場所から 避難所までの最短経路の距離を，図-6 に津波避難タワ 一がない場合の，図-7 に津波避難タワー有りの場合の 図を示す，津波避難タワーの整備によって，特に沿岸部 から避難する際の避難経路距離が大きく改善されている ことがわかる.

また津波避難シミュレーションの結果から，死亡率 と避難開始時間の関係のグラフを図-8, その差を図-9 に示寸，避難開始時間が 0 600 s では，津波避難タワー の整備前後に関わらず死亡率は $0 \%$ となり，避難開始時 間を 10 分以内にできたら, 津波避難タワーの有無に関 わらず死亡者が出ないことがわかった。避難開始時間が $700 \mathrm{~s}$ を超えると，津波避難タワーが無い場合に被害に 遭う人が出てくるが，津波避難タワーが有ると避難開始 時間が $800 \mathrm{~s}$ までは死亡率は $0 \%$ であった。避難開始時 間が $900 \mathrm{~s}$ から $1500 \mathrm{~s}$ までは, 津波避難タワーの有無に 関わらず，次第に死亡率は高くなっていくが，津波避難 タワーによって死亡率が抑えられていることが確認でき る. しかし, 避難開始時間が $1600 \mathrm{~s}$ を超えると共に死亡 率は $100 \%$ となった。

表-1＼cjkstart避難シミュレーションの詳細な条件

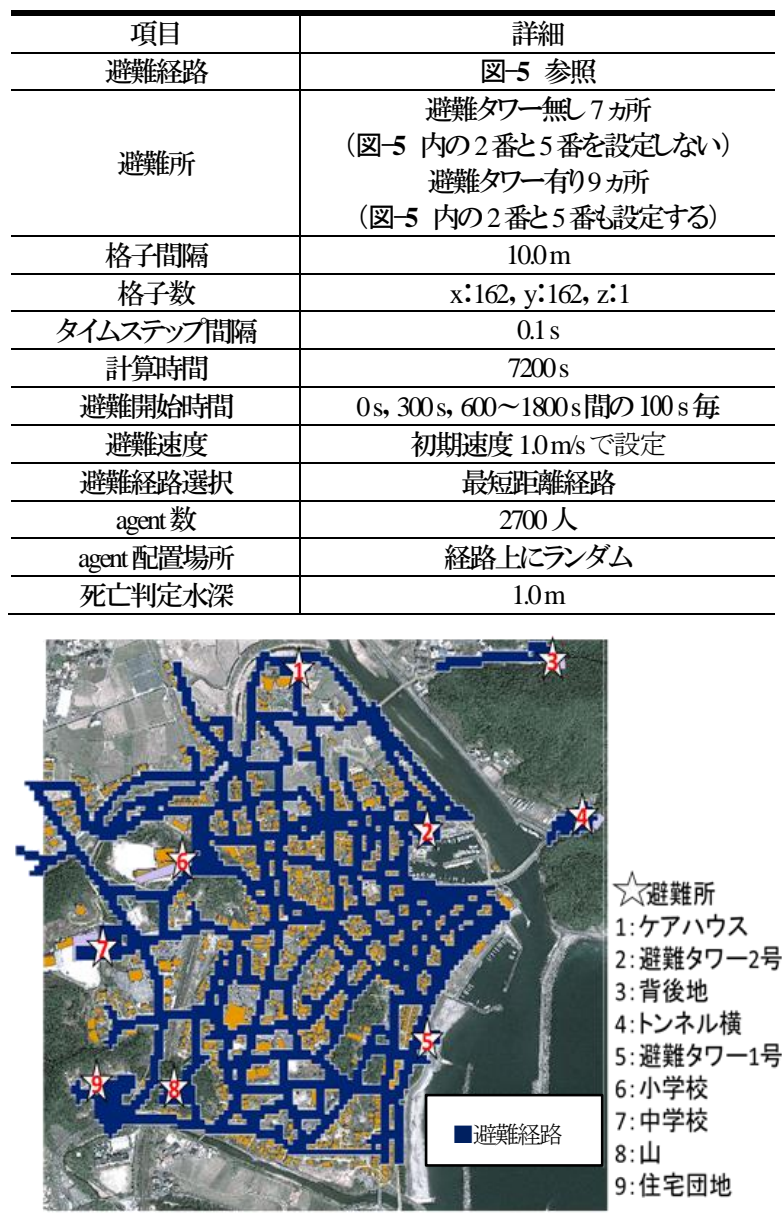

図-5 避難経路と避難所の設定

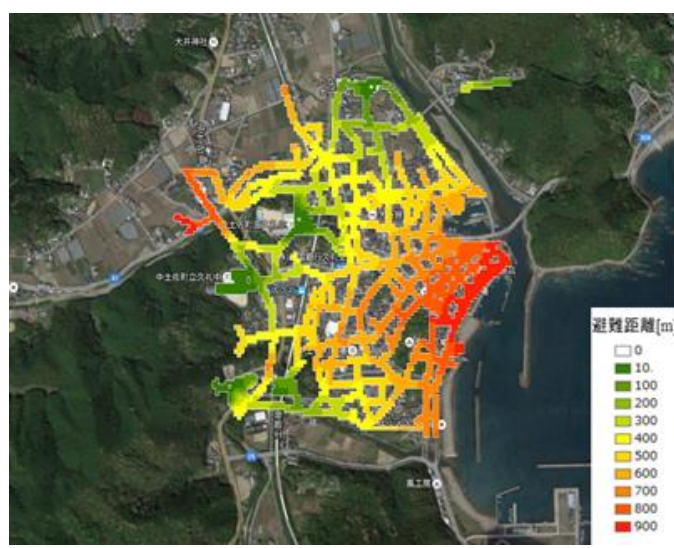

図-6 避難タワー無しの場合の避難経路距離

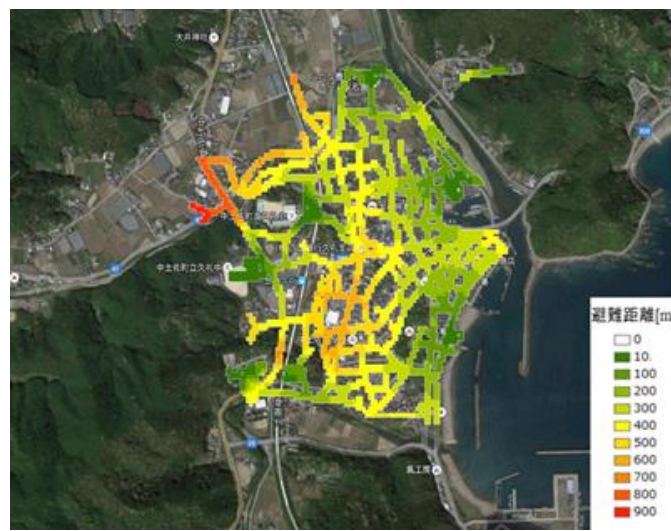

図-7 避難タワー有りの場合の避難経路距離

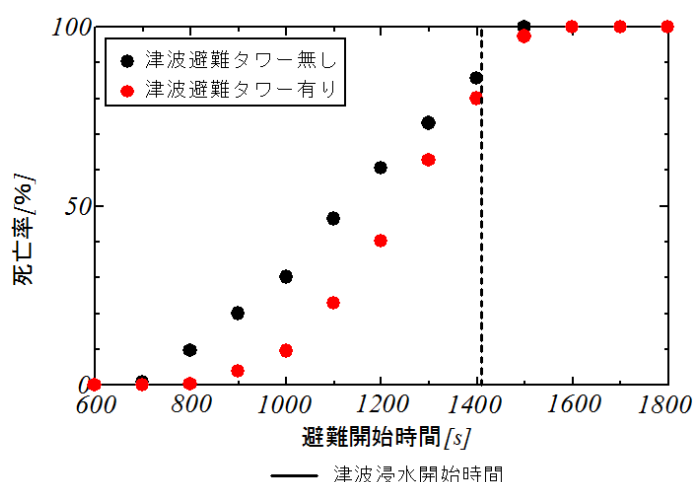

図-8 避難開始時間と死亡率の関係

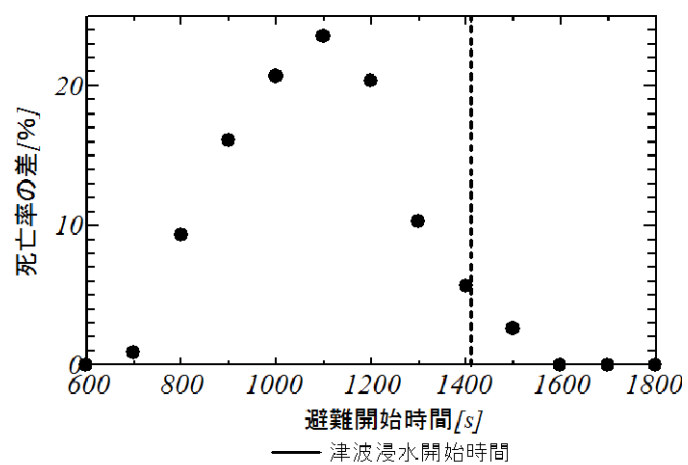

図-9 津波避難タワーの有無による死亡率の差 
避難開始時間によっては，津波避難タワーが整備され たとしても，人的被害が発生しており，早期避難が重要 であることがわかる。.また対象地域においては津波避難 タワー1 号の地点では，津波浸水時間は約 $1410 \mathrm{~s}$ であり 津波の浸水が開始する前に避難を開始しても津波に遭遇 する可能性がある. また浸水が開始してから避難した場 合では，死亡率が 80 \%以上になることがわかった.さ らに，避難開始時間による津波避難タワーの効果を検討 するため, 津波避難タワーの有無による死亡率の差をグ ラフにしたものを図-9 に示す．避難開始時間が $800 \mathrm{~s} \sim$ $1300 \mathrm{~s}$ では，津波避難タワーの整備によって死亡率が約 $10 \%$ 以上改善でき，特に 1000～1200 s では，死亡率を $20 \%$ 以上抑えることができる．このことから，避難開 始が $700 \mathrm{~s}$ を超えて $1600 \mathrm{~s}$ までに避難する場合において, 津波避難タワーの有効性を確認することができたと考え る.

\section{4. 避難所までの距離別の津波避難タワーの効果}

\section{(1) 避難シミュレーションの計算条件}

前章では避難開始時間毎の死亡率を算出した．次に， 避難開始場所から避難所までの距離毎の死亡率を算出し, 津波避難タワーの効果を検討する.

そこで避難開始場所から避難所までの距離を50 m毎に 分類し, 分類した場所毎にシミュレーションを行った. 例えば，避難所までの距離が500〜 550 mの場所を算出し， その場所を赤色で示した図を，図-10には津波避難タワ 一が無い場合，図-11には津波避難タワーが有る場合の 図を示す。津波避難タワーの有無のそれぞれの場合にお いて，分類した場所に200名のagentをランダムに配置し た. また，避難開始時間は100 s 毎に設定した. agent数, agent配置位置，避難開始時間以外の計算条件は表-1と同 じである.

\section{(2) 避難シミュレーションの計算結果}

避難経路距離毎の避難シミュレーションを行い, 避難 所までの距離毎に死亡率が0\%でなくなる避難開始時間 を算出した. これにより, 分類した距離毎に避難できる 最大の避難開始時間を算出した。この時間を避難開始限 界時間とし，避難経路距離との関係を図-12に示す．避 難経路距離が500～550 mまででは，津波避難タワーがあるこ とで限界避難可能時間が短くなっているが，これは沿岸に近い 場所に津波避難タワーがあることで，agentの配置位置も沿岸に 近くなり，津波に遭遇する時間が早くなるからであると考える. 一方で, 避難経路距離が600〜 650 mより長くなると, 津 波避難タワーの設置により避難を可能にする時間を $100 \mathrm{~s}$ から200s稼ぐことができることがわかった.

\section{5. 避難経路距離の変化による避難行動への影響}

\section{(1) 避難シミュレーションの計算条件}

津波避難タワー有無によって，避難所までの距離が 変わることは図-6,7からわかる. そこで避難開始場所 から避難所までの距離が変化した場所，つまり津波避難 タワーを整備したことによって避難経路距離が短くなっ た場所を $100 \mathrm{~m}$ 毎に分類して, 避難シミュレーションを 行った. $100 \mathrm{~m}$ 毎に分類した場所に色付けをし, 図-13に 示す. agentは分類した場所毎に 200 人をランダムで配置 した。また，避難開始時間は1200 sに一斉に開始するよ うに設定した，agent数，agent配置位置，避難開始時間以 外の計算条件は表-1と同じである.

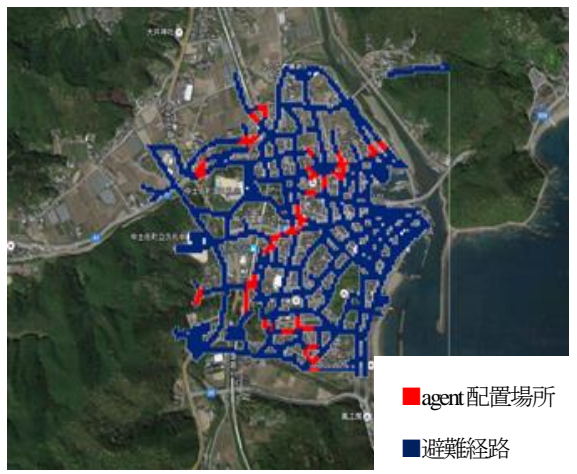

図-10 避難所までの距離 $(500 \sim 550 \mathrm{~m})$ （津波避難タワー無しの場合）

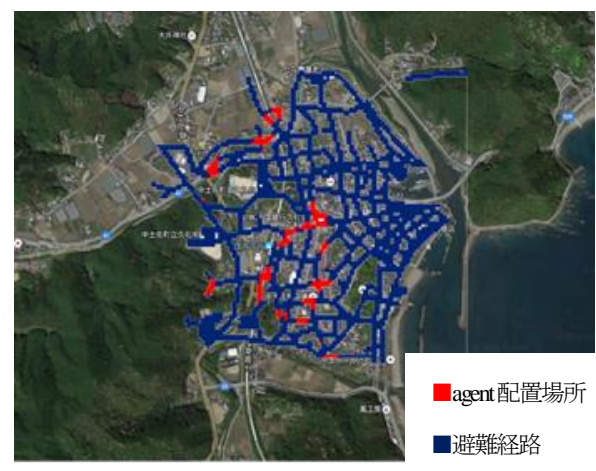

図-11避難所までの距離 $(500 \sim 550 \mathrm{~m})$ （津波避難タワー有りの場合）

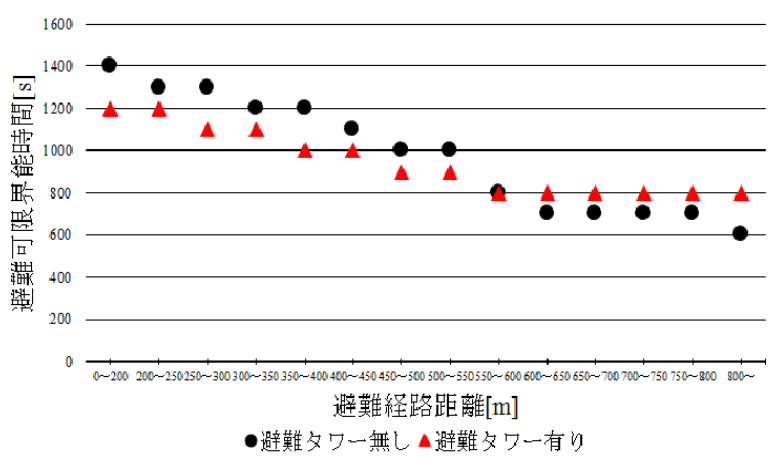

図-12 避難経路距離毎の限界避難可能時間 
(2) 避難シミュレーションの計算結果

避難所までの距離が変化した場所と死亡者数の結果を

図-14に示寸．また，津波避難タワーの有無による死亡 者数の差を算出したものを図-15に示す。これらの結果 より, 避難経路距離が $300 \mathrm{~m}$ 以上変化した場所からの避 難では, 津波避難タワーによって死亡者数を減少させる ことができることができ，津波避難タワーの有効性を確 認することができた。 しかし，避難経路距離が100～300 $\mathrm{m}$ までしか変化しない場所からの避難では, 津波避難夕 ワーの有効性はあまりないことがわかった.

また, 避難経路距離が 0 〜 $100 \mathrm{~m}$ しか変化しない場所か ら避難する場合では，津波避難タワーへ避難することで 死亡者数が多くなってしまうことがわかった．これは図 -3からわかるように津波浸水到達時間が早い沿岸部に津 波避難タワーがあることで，津波が来襲する方向へ逃げ るようになったためだと考える．ただし，本研究では， 避難開始時間を1200 sに設定していることを考慮する必 要があると考える.

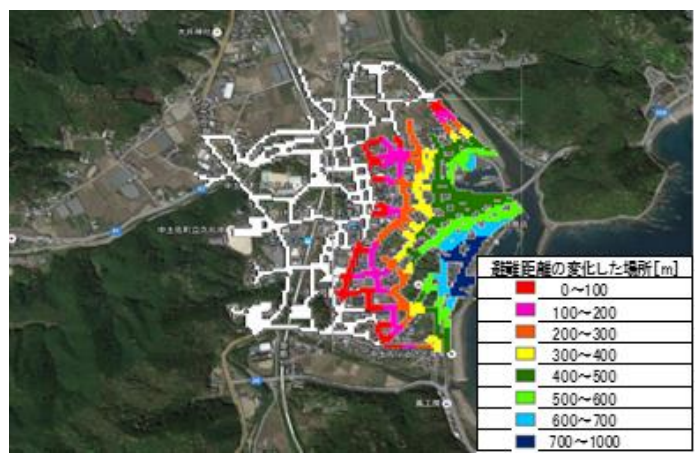

図-13 避難所までの距離の変化した場所を $100 \mathrm{~m}$ 毎に分類

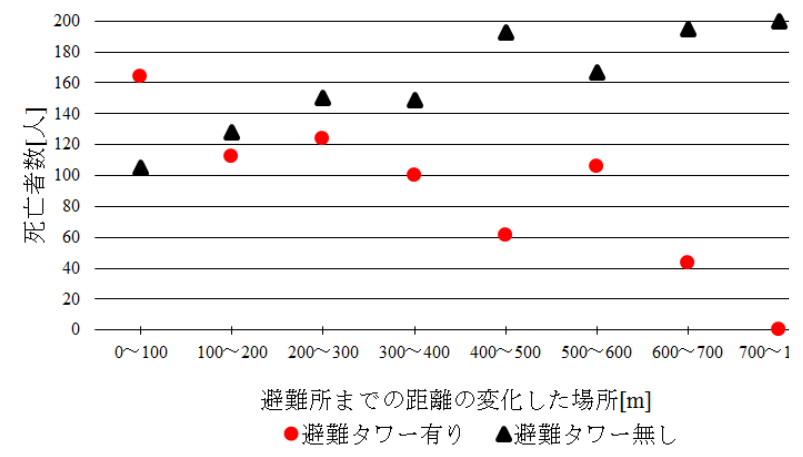

図-14 距離が変化した場所と死亡者数の結果

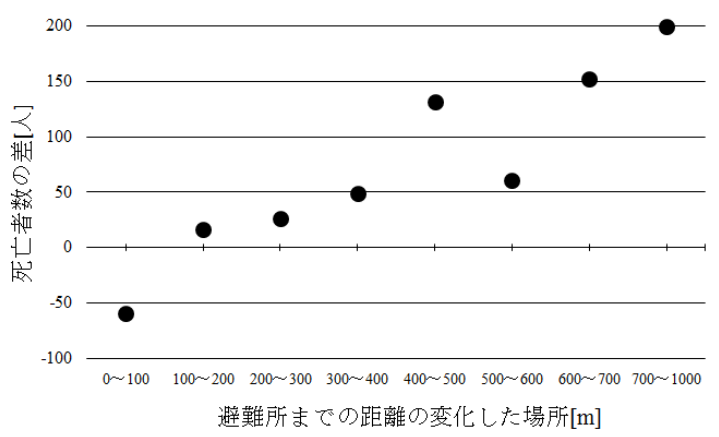

図-15 津波避難タワーの有無による死亡者数の差

\section{6. 新たな津波避難タワーの整備場所の検討}

(1) 避難シミュレーションの計算条件

以上の結果より，津波避難タワーの有用性が確認でき たと同時に，設置場所も極めて重要であることがわかっ た．そこで，今後新たに津波避難タワーを設置するにあ たって，津波避難シミュレーションを用いて，最適な夕 ワーの設置場所を検討する.

\section{(2) 避難シミュレーションの計算結果}

図-6,7の避難経路距離や前章までの結果から，新た な津波避難タワーの設置場所を6力所選定した。 そこに 新たな津波避難タワーを設定し，シミュレーションを行 った．避難シミュレーションの計算条件は避難開始時間 を1200 sに設定した他は，表-1と同じである．新たに設 定した6ケースの津波避難タワーの場所と，各ケースの 平均避難距離と死亡者数の関係を図-16，17に示寸。

本研究では，ケース3で設定した位置に新たな津波避 難タワーを整備すると, 津波避難タワーの効果は最大と なり，津波避難タワー2基の場合に比へ，平均避難経路 距離を約 $12 \%$ ，死亡者数を約 45 \%減少させることがで きることがわかった．また，平均避難経路距離がほぼ等 しいケース 1 とケース50比較から, 最短経路で避難する 際に津波が来襲する方向から離れるような場所に，新た な津波避難タワーを整備することを提案する.

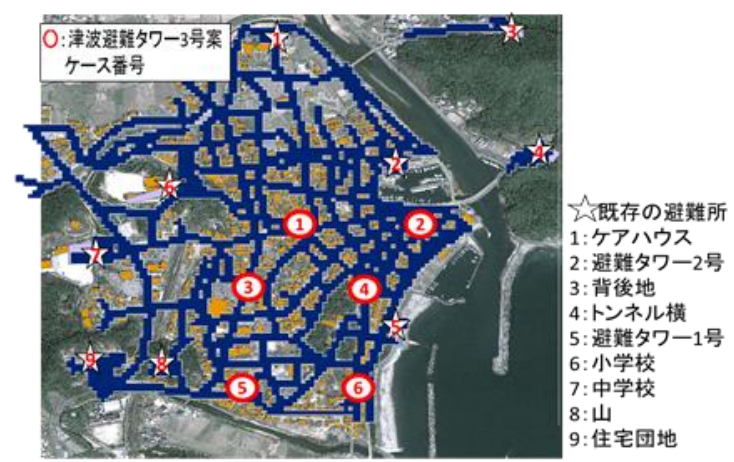

図-16 新たに設定した津波避難タワーの位置

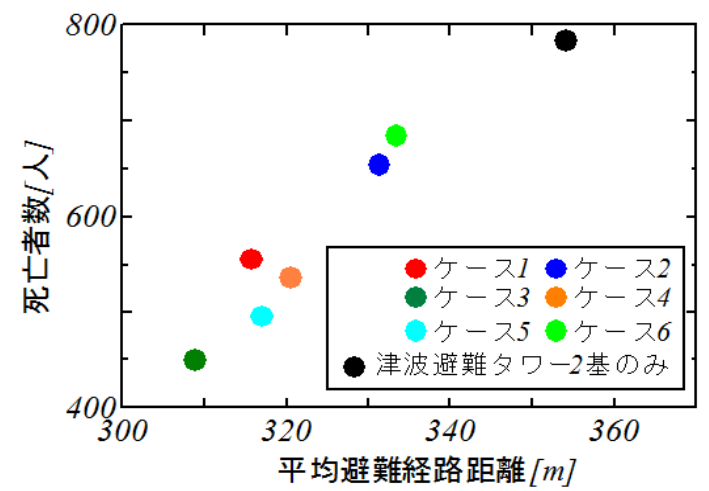

図-17 各ケースの平均避難距離と死亡者数の関係 


\section{7. おわりに}

本研究では，最短経路で避難する津波避難シミュレー ションを用いて，津波避難タワーを整備した地区を対象 に，避難開始時間や避難経路距離，限界避難可能時間を 算出し, 津波避難タワーの有効性を定量的に確認するこ とができた.

しかし，沿岸部の津波避難タワーと内陸部の避難所ま での避難経路距離に $300 \mathrm{~m}$ 程度しか差がない場所からの 避難では，避難開始時間によっては沿岸部にある津波避 難タワーに避難することで，津波に遭遇し被害が大きく なる場合もあることがわかった．また，新たな津波避難 タワーの設置位置の検討及び提案した. 今後, 津波避難 シミュレーションを用いて，本研究で抽出した問題点を 住民の忙議論するなどをして，実際の避難行動への 活かし方も考えていきたい.

謝辞 : 公益社団法人 日本地震工学会 津波などの突発大 災害からの避難の課題と対策に関する研究委員会には, 避難経路並びに避難所等のデータの提供いただいた。 こ こに記して，感謝の意を表す。

\section{参考文献}

1) 国土交通省都市局 : 津波防災まちづくりの計画策定に係る 指針，URL: http://www.mlit.go.jp/toshi/toshi_gairo_tk_000031.html, 参照2015-06-11.

2) 内閣府 : 津波避難ビル等に係るガイドライン,

URL: http://www.bousai.go.jp/kohou/oshirase/h17/pdf/guideline.pdf, 参照 2015-07-09.

3）伊藤渚生，一八瀬友博 : 津波避難場所選定指標を用いた現 状の避難ビル適地選定分析-鎌倉市における事例研究-，都 市計画報告書，No.13，pp.156_159，2015.

4) 熊谷兼太郎 : 2011 年東北地方太平洋沖地震津波の避難行動 への津波避難シミュレーションの適用性，国土技術政策総 合研究所資料 No.742，2013.

5) 有川太郎, 大家隆行 : 数值波動水槽と連成した避難シミュ レーションによる避難行動特性についての検討，土木学会 論文集 B2(海岸工学)，Vol.71，No.2，pp.I_319-I_324，2015.

6) 内閣府 : 南海トラフの巨大地震モデル検討会,

URL: http://www.bousai.go.jp/jishin/nankai/model/index.html, 参照2016-01-21.

(2016.316受付)

\title{
STUDY OF THE EFFECT OF THE TSUNAMI EVACUATION TOWER USING THE TSUNAMI EVACUATION SIMULATION
}

\author{
Yuki KOYANAGI and Taro ARIKAWA
}

\begin{abstract}
This study attempts to investigate effect of a tsunami evacuation tower by using evacuation simulator is coupled with tsunami simulator. This simulator calculates the behavior of evacuation and tsunami at the same time. Thus, the difference of the human suffering and the impact on the evacuation behavior were validated. As a result, in this study's conditions, when the evacuation tower was established at the location near coastal area, it was confirmed possibility to encounter tsunami rises depending on the evacuation start time. On the other hand, when evacuation starts earlier than tsunami arrival time, it was confirmed that it is possible to significantly reduce the death rate. Finally, the effect of new tsunami evacuation tower was validated. As a result, it was confirmed that the death rate is decreased by shortening the average evacuation distance.
\end{abstract}

